Portland State University

PDXScholar

$5-5-2017$

\title{
Patterns and Impacts of Urban Stream Burial and the Potential for Stream Daylighting in Portland, Oregon
}

\author{
Ella Weil
}

Portland State University

Follow this and additional works at: https://pdxscholar.library.pdx.edu/honorstheses

\section{Let us know how access to this document benefits you.}

\section{Recommended Citation}

Weil, Ella, "Patterns and Impacts of Urban Stream Burial and the Potential for Stream Daylighting in Portland, Oregon" (2017). University Honors Theses. Paper 375.

https://doi.org/10.15760/honors.373

This Thesis is brought to you for free and open access. It has been accepted for inclusion in University Honors Theses by an authorized administrator of PDXScholar. Please contact us if we can make this document more accessible: pdxscholar@pdx.edu. 


\title{
Patterns and Impacts of urban stream burial and the potential for stream daylighting in Portland, Oregon
}

\author{
by \\ Ella Weil \\ An undergraduate honors thesis submitted in partial fulfillment of the \\ requirements for the degree of \\ Bachelor of Science \\ in \\ University Honors \\ and
}

Geography

Thesis Adviser

Heejun Chang

Portland State University

2017 
"For more than two hours yesterday Johnson and Tanner Creeks were turned from their beds, and poured their yellow torrents through paved streets, filling cellars of some of the fine residents along the foot of the hill, tearing deep ruts in gutter drains, overturning wooden sidewalks, and temporarily impeding street traffic in many places. So great was the volume of water that people generally thought that the costly sewers that were built to swallow up the troublesome creeks, had burst, and preparations were in progress for a general exodus, when the flood suddenly receded." - The Oregonian, January 13, 1895.

\section{Abstract:}

Over the last 150 years, many urban areas have seen streams disappear underground into sewer systems and pipes. Stream burial, the rerouting of open channels to pipes and culverts, has a strong positive correlation with urban development. Patterns of development contributing to stream burial include the building of freeways, roads, sewer infrastructure, and residential housing. This study uses a combination of archival analysis, spatial analysis, and statistical methods to determine the patterns and impacts of stream burial in Portland, Oregon. Urban stream deserts have been identified in many metropolitan areas and can be defined as areas with dense urban development that have lost all hydrological connectivity. This study discusses the history of stream burial in Portland, delineates Portland's urban stream desert and identifies ecological impacts associated with stream burial. Spatial analysis shows the hotspots of stream deserts are concentrated in east Portland where both impervious areas and pipes are highly copresent. Water quality analysis is conducted by comparing five urban subwatersheds with varying degrees of burial and identifying the differences in water quality between upstream open channels and downstream buried reaches. While the ecological impacts of stream burial are not uniform, it can be argued that there is a relationship between stream burial and stream degradation. The results from the available data show significant differences between the 
upstream and downstream sites in three streams for several water quality parameters, and two streams that showed very little difference between upstream and downstream sites. The streams with the greatest variance in land use across the subwatershed had the most significant changes in water quality between the upstream and downstream sites. This study concludes by looking at stream daylighting as an option for both ecological restoration and social benefits. Recent efforts to design around existing nature and daylight streams in urban environments have contributed to improved water quality, increased biodiversity, community engagement, and reduced strain on aging sewer infrastructure.

Key words: Stream Burial, Urban Streams, Stream Daylighting, Water Quality, Urban Stream Syndrome, Urban Stream Desert.

\section{Introduction:}

Stream burial is a common pattern of urban development that originated in the late $1800 \mathrm{~s}$ with early urbanization. Over the last 150 years, stream channels across urban areas have been altered, buried, and diverted, creating riverless urban centers called urban stream deserts (Napieralski et al., 2015). These urban stream deserts have been identified in several cities across the U.S. and follow similar patterns of dense population and high percentages of impervious area. These areas often suffer from reduced drainage capacity, increased infrastructure expenses, degraded water quality, and diminished aquatic habitat (Walsh et al, 2005; Elmore \& Kauchal, 2008; Jacobson, 2010; Napieralski et al., 2015)

Piecing together the historic paths of Portland's streams is an interpretive art as streams have been buried, diverted, culverted and piped, while the urban core has been flattened to accommodate growth. Portland's urban core, located in the lower Willamette Basin, was 
historically characterized by vast hydrological connectivity and hydric soils with wetlands and lakes supporting abundant aquatic life (Douglas, 1914). Several tributaries in Portland's urban forest, Forest Park, flow in open channels until they abruptly disappear underground into pipes below railroad tracks and industrial areas; reappearing at their final destination at the Willamette River. Outside of the urban forests, some streams flow in and out of pipes along their route to the Willamette, while others have been buried completely and combined into the sewer systems.

While several streams run underground in Portland's deteriorating stormwater and sewer infrastructure, others are re-routed through backyards and perforated pipes in residential and commercial areas. The 80-year-old stormwater/sewer system designed to handle these streams is currently experiencing decreased capacity for runoff resulting in leakage, reduced water quality, combined sewer overflow events, increased flood risk, and significant operations and maintenance costs (Broadhead et al, 2015; BES, 2016). The ecological impact of urban development on streams is widely referred to as urban stream syndrome; a condition that includes poor water quality, channel degradation, habitat loss and flashy hydrographs (Walsh et al, 2005). While stream degradation is associated with urbanization, the impacts are not uniform over space and time. Stream health is dependent on a variety of factors and will vary by geography and hydrometeorological conditions (Tong \& Chen, 2003; Walsh et al, 2005, Chen and Chang 2014). The effects of pipes on stream health across a number of different small watersheds have relatively understudied.

Stream daylighting is the re-creation of open channels from buried, piped, or culverted streams. Benefits of stream daylighting include reduced peak flows, improved water quality, improved habitat for biological communities, increased hydrological connectivity, erosion reduction, and resilience against flooding (Pinkham, 2000; Smith, 2007; Wild et al; 2010, Neale 
\& Moffett 2016). A daylighting study conducted in New Zealand revealed immediate changes in taxa between pre and post daylighting with a dramatic increase in biodiversity in the daylighted reaches (Neale \& Moffett, 2016). Zurich, Switzerland has implemented a citywide stream daylighting policy resulting in the restoration of over 10 miles of open channels and a reduction of approximately $37 \%$ of surface water runoff to the combined sewer system (Conradin \& Buchli, 2004; Smith, 2007). Stream daylighting projects in Seattle and San Francisco have documented positive impacts on species biodiversity, stormwater management and community engagement (Pinkham, 2000; Smith, 2007).

In an urban environment, it is often only feasible to daylight small reaches of streams on parcels of public land. While this may not be conducive to broader ecological benefits, nor is it ideal for a holistic approach to watershed management, the social benefits endure. It can be argued that social and ecological perspectives in restoration are of equal importance. Interdisciplinarians interested in urban ecology have seen a recent emphasis on the social functions of human-nature interactions and the ecological impacts of a positive perception of nature (Miller, 2002; Miller et al, 2006; Standish et al, 2012). Researchers in the field of conservation psychology have shown the positive cognitive and affective responses to nature, as well as the importance of education and play in influencing positive human perceptions of nature (Clayton \& Meyers, 2009). Given the positive social impacts of stream daylighting, it would be ideal to identify areas where a daylighting project would be a service to people in the low to medium income bracket and where population is dense.

The purpose of this study is thus to determine the impacts of urban stream burial in Portland and identify potential areas for stream daylighting. This study compares five urban subwatersheds with varying degrees of burial that collect varying types of runoff. The streams 
are evaluated based on the comparison of water quality attributes as a reference for the ability to support aquatic life. The results of these conditions can be used not only to support the argument for stream daylighting, but also to prevent further stream burial to vulnerable places. The combination of water quality analysis and a review of stream daylighting potential will reveal that stream daylighting not only provides aquatic habitat and ecosystem services, but also demonstrates the important intersection between urbanization and conservation.

This study seeks to answer the following questions:

1. What is the history of urban stream burial that has resulted in Portland's urban stream desert?

2. What is the spatial pattern of stream burial and how does that relate to impervious area?

3. What are the impacts of stream burial on water quality between upstream and downstream?

4. Where are the potential areas for stream daylighting to increase both ecological and social benefits?

\section{Study area:}

This study identifies characteristics of five subwatersheds located in the lower Willamette Basin. The study area consists of Tanner, Doane, Miller, Saltzman, and Stephens Creek subwatersheds (Figure 1). These subwatersheds were chosen because they represent a range of disturbance and they are located in west side of the Willamette river basin to control for other potentially confounding factors. Table 1 summarizes the land use and zoning characteristics of each study subwatershed. 


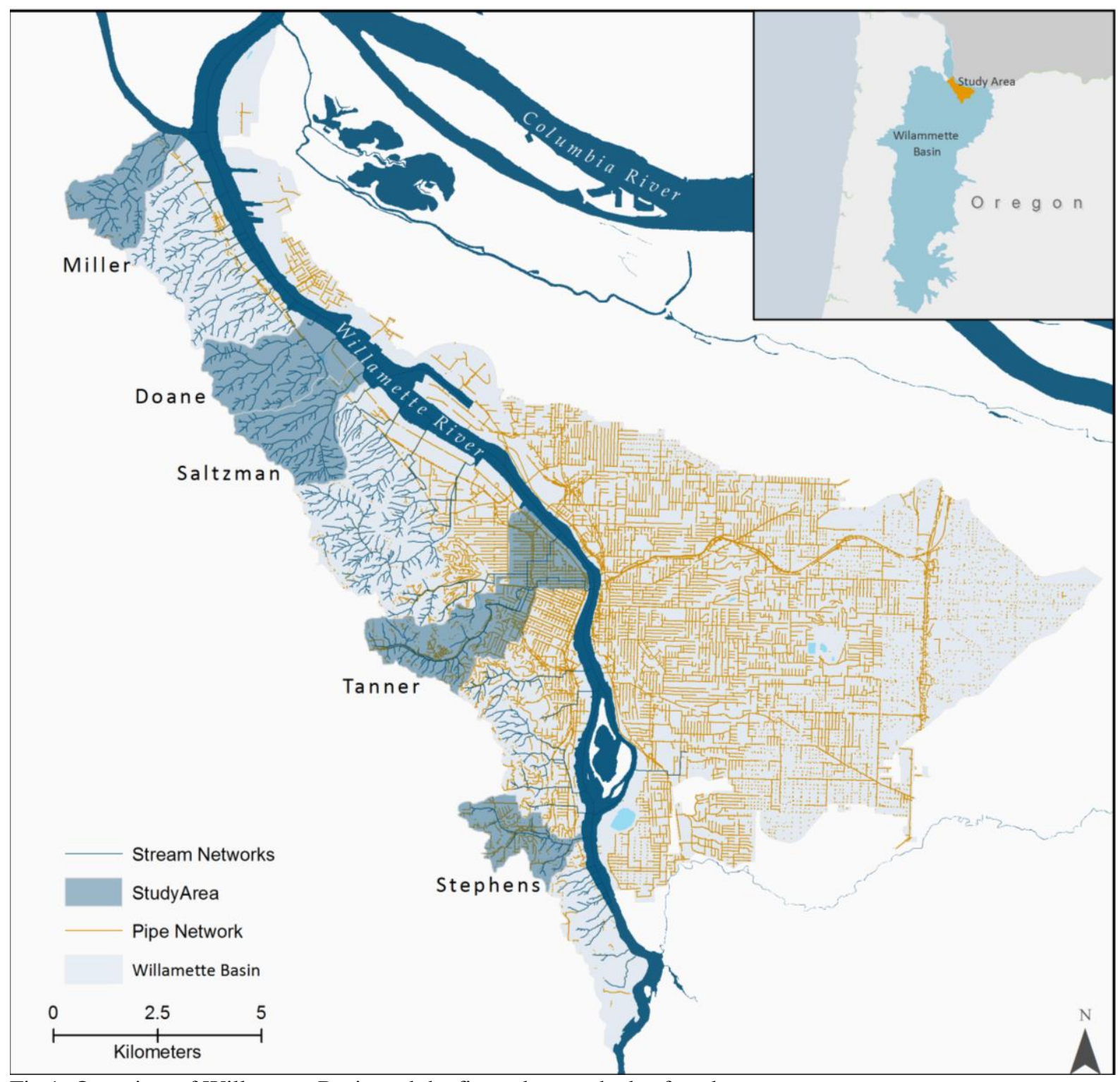

Fig 1: Overview of Willamette Basin and the five subwatersheds of study.

Tanner Creek is piped from its headwaters in a conservation zone to its confluence at milepost 11 in the Willamette River. Tanner Creek runs in pipes directly under Portland's urban core and has cultural importance as one of the city's most well-known lost streams. The majority of the pipe is fed from the remaining intermittent headwater streams of Tanner Creek and the adjacent stream Johnson Creek. Runoff from roads enters the pipe after being filtered through a series of swales before disappearing underground for its conveyance route to the river. 
Doane, Miller, and Saltzman Creeks each originate in Portland's West Hills and flow in open channels through the commercial forest area and environmental protection zones in Forest Park before they are piped under major industrial areas. Saltzman and Doane Creeks flow entirely in open channels through Forest Park until reaching Highway 30, a main arterial, where they are forced through culverts and open concrete channels under the railroads and industrial areas. Saltzman Creek reappears in its final 300 feet where it meets the Willamette River. Miller Creek, with the highest percent of open channel, flows through a culvert only under Highway 30 and the railroads.

While the majority of Stephens Creek flows in an open channel, it has been heavily altered by residential land use and a very moderate amount of open space and environmental zones. There are several major corridors that intersect and follow the creek before it reaches the Willamette River. Stephens Creek is characterized as highly urbanized and will be used as a comparison for the other streams in the study.

\begin{tabular}{|c|c|c|c|c|c|c|c|c|c|c|}
\hline \multirow{2}{*}{$\begin{array}{l}\text { Subwatershed } \\
\text { Land use }\end{array}$} & \multicolumn{2}{|l|}{ Tanner } & \multicolumn{2}{|l|}{ Doane } & \multicolumn{2}{|l|}{ Miller } & \multicolumn{2}{|l|}{ Saltzman } & \multicolumn{2}{|l|}{ Stephens } \\
\hline & $\begin{array}{l}\text { Area } \\
\text { (hectares) }\end{array}$ & $\begin{array}{l}\% \text { of } \\
\text { Total }\end{array}$ & $\begin{array}{l}\text { Area } \\
\text { (hectares) }\end{array}$ & $\begin{array}{l}\% \text { of } \\
\text { Total }\end{array}$ & $\begin{array}{l}\text { Area } \\
\text { (hectares) }\end{array}$ & $\begin{array}{l}\% \text { of } \\
\text { Total }\end{array}$ & $\begin{array}{l}\text { Area } \\
\text { (hectares) }\end{array}$ & $\begin{array}{l}\% \text { of } \\
\text { Total }\end{array}$ & $\begin{array}{l}\text { Area } \\
\text { (hectares) }\end{array}$ & $\begin{array}{l}\% \text { of } \\
\text { Total }\end{array}$ \\
\hline Open Space & 176 & $22.8 \%$ & 349 & $66.2 \%$ & 206 & $54.3 \%$ & 242 & $55.3 \%$ & 64 & $21.0 \%$ \\
\hline Industrial & 19 & $2.6 \%$ & 112 & $21.1 \%$ & .9 & $.3 \%$ & 36 & $8.2 \%$ & & \\
\hline Residential & 355 & $46.0 \%$ & 2 & $0.3 \%$ & 10 & $2.6 \%$ & 5 & $1.0 \%$ & 212 & $69.7 \%$ \\
\hline Commercial & 219 & $28.6 \%$ & & & & & & & 28 & $9.0 \%$ \\
\hline $\begin{array}{r}\text { Commercial \& } \\
\text { Res Forest }\end{array}$ & & & 64 & $12.2 \%$ & 163 & $42.8 \%$ & 155 & $35.3 \%$ & & \\
\hline Total Area & 769 & $100.0 \%$ & 527 & $100.0 \%$ & 380 & $100.0 \%$ & 439 & $100.0 \%$ & 305 & $100.0 \%$ \\
\hline $\begin{array}{r}\text { Environmenta } \\
\text { I Zones }\end{array}$ & 170 & $22.1 \%$ & 395 & $75.0 \%$ & 267 & $70.1 \%$ & 322 & $73.0 \%$ & 49 & $16.0 \%$ \\
\hline $\begin{array}{r}\text { Impervious } \\
\text { Area }\end{array}$ & 351 & $43.5 \%$ & 33 & $6.2 \%$ & 13 & $3.3 \%$ & 31 & $7.5 \%$ & 98 & $32.0 \%$ \\
\hline $\begin{array}{r}\text { Mean } \\
\text { Elevation } \\
\text { (meters) }\end{array}$ & & 125 & & 184 & & 197 & & 216 & & 128 \\
\hline
\end{tabular}

Table 1. Land use and zoning characteristics of each study subwatershed 


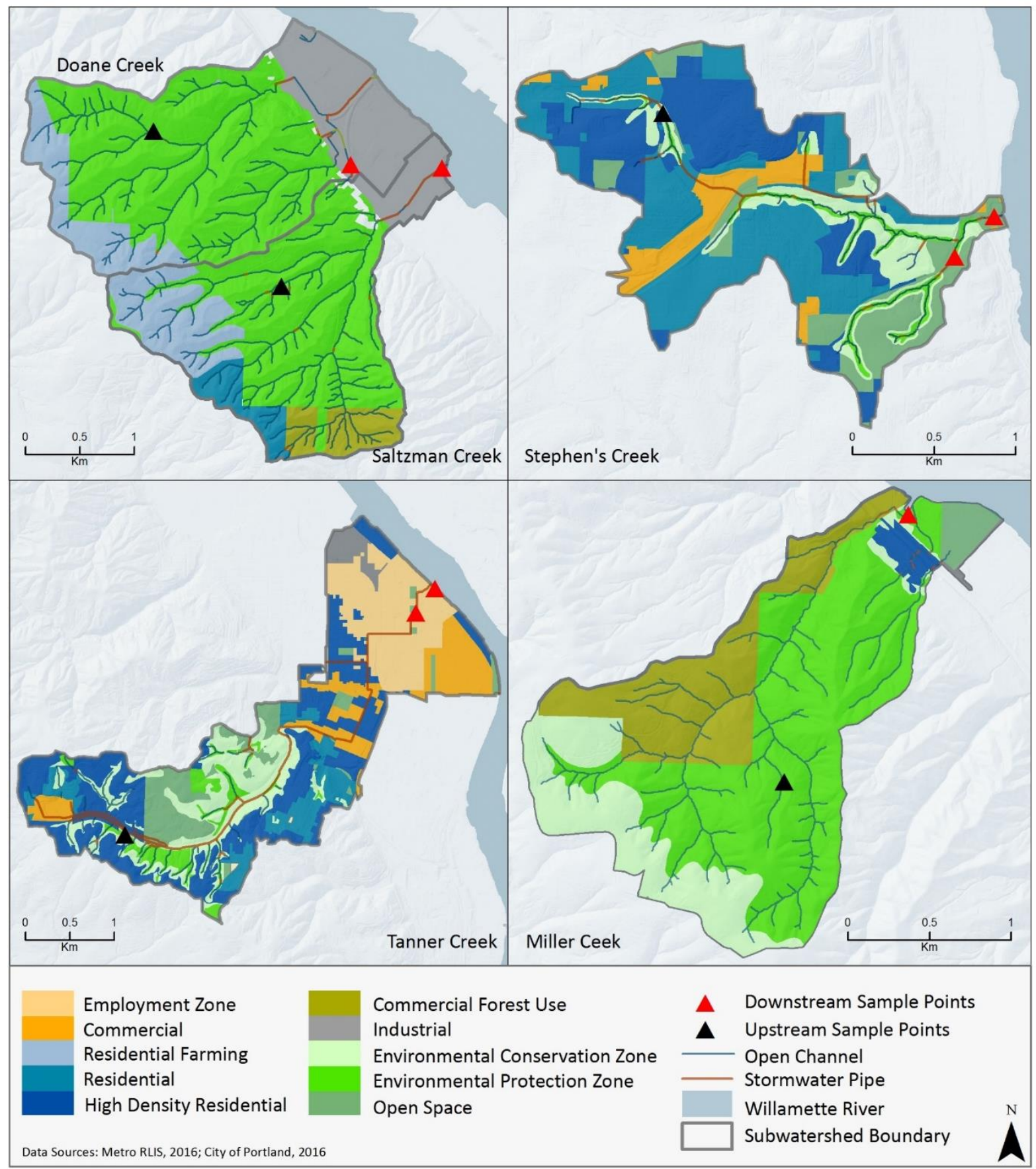

Fig 2: Land use and zoning by subwatershed. Figure includes upstream and downstream monitoring locations for water quality analysis. 


\section{Data and Methods:}

\subsection{Data}

The water quality data used for analysis include stream temperature, $\mathrm{pH}$, Dissolved Oxygen (DO), conductivity, and Total Suspended Solids (TSS) (Table 2). Each of these parameters are physical indicators of stream health and can be useful in identifying areas with restoration potential. Conductivity is the measurement of water to carry an electrical current and it can be used to determine mineralization and dissolved solids in water. Total Suspended Solids can be used a surrogate parameter to water quality as an indicator of metals and organic compounds which are absorbed and transported by TSS (Wilbur \& Clark, 2001). Elevated concentrations can have a negative effect on aquatic life. Temperature can be monitored to determine the ability of a stream to support aquatic habitat. Changes in stream temperature can occur from increased impervious area, reduced base flow, or changes in chemistry. DO is measured to quantify potential reduction in stream riffle and stream bank complexity and $\mathrm{pH}$ is measured to identify potential impacts of land use expressed in changes in the acidity of the water.

The water quality data consists of monthly grab samples collected by the City of Portland Bureau of Environmental Services between 2008 and 2016. The sample points include upstream and downstream monitoring locations (Fig 2). Upstream samples were taken from open channels in environmental protection or conservation areas. Downstream samples were taken from pipes, culverts, or outfalls. For each stream in the study, the downstream reaches are considered to be heavily altered by development. Several other GIS shapefiles were obtained from local government offices for deriving historical streams and land use conditions of each subwatershed. 


\begin{tabular}{|l|l|l|}
\hline Data & Type & Source \\
\hline Water Quality & $\begin{array}{l}\text { Temperature, pH, Dissolved Oxygen (DO), } \\
\text { Specific Conductivity, and Total Suspended } \\
\text { Solids (TSS) }\end{array}$ & $\begin{array}{l}\text { City of Portland Bureau of Environmental Services, } \\
2008-2016\end{array}$ \\
\hline $\begin{array}{l}\text { Historic } \\
\text { Streams }\end{array}$ & $\begin{array}{l}\text { Digital Elevation Model, Cadastral Surveys, } \\
\text { Digital Sanborn Maps }\end{array}$ & $\begin{array}{l}\text { CSAR, 2016; City of Portland Archives; The } \\
\text { Oregonian, 1850-1860; Oregon Historical Society; } \\
\text { Multnomah County Library }\end{array}$ \\
\hline $\begin{array}{l}\text { Current } \\
\text { Streams }\end{array}$ & Stream Networks & $\begin{array}{l}\text { City of Portland, 2016; Portland Maps, 2016; RLIS, } \\
\text { 2016; CSAR 2016 }\end{array}$ \\
\hline Infrastructure & Stormwater and Sewer & $\begin{array}{l}\text { City of Portland, 2016; Portland Maps, 2016; RLIS, } \\
2016\end{array}$ \\
\hline Land use & $\begin{array}{l}\text { Impervious area, Environmental Overlay, } \\
\text { Development }\end{array}$ & $\begin{array}{l}\text { City of Portland, 2016; Portland Maps, 2016; RLIS, } \\
2016\end{array}$ \\
\hline
\end{tabular}

Table 2: Sources and types of data used in this study

\subsection{Archival Analysis}

Portland's urban stream desert can be determined by identifying the loss of open channels in heavily developed areas once identified as places with hydrologic connectivity. Archival research became necessary in order to understand the historic hydrologic landscape of Portland. The Oregon Historical Society and the City of Portland Archives have made cadastral surveys from the mid to late 1800s available. Some of these maps have been included in this study, while others were used as an overall reference. City sewer infrastructure plans were obtained from the City of Portland Archives which confirmed the conversion of several streams on the east side of Portland into sewer basins. The sewer basins that swallowed the streams have in many cases been named in correspondence with the original stream names providing clues to the historic flow paths. Digitized Oregonian articles and memoirs of Portland's early pioneers are included in this study for their detailed descriptions of landscape characteristics prior to urban development. Combined, these documents provide insight not only to Portland's urbanization process, but also to the shifting attitudes toward streams and rivers in an urban environment. 


\subsection{GIS and Spatial Analysis}

This study explores relationships between urban development and urban streams through a series of GIS and spatial analysis. GIS analysis of stormwater pipe networks and impervious surface area were used to identify patterns in urban development. Kernel Density analysis was run to visually identify patterns in the distribution of pipe networks and impervious areas and to determine their spatial relationship with open stream channels. Nearest Neighbor analysis was used to identify statistically significant clustering of streams, impervious area and pipe vertices. Zoning and land use designations were used to determine differences in land use throughout each subwatershed in the study.

The urban stream desert was derived from Getis-Ord G* Hot Spot analysis of pipe vertices and impervious area (Getis \& Ord, 1995). The Getis-Ord G* Hotspot outputs were rasterized and merged to distinguish existence of a stream desert. The stream desert is identified in the instance that both impervious area clustering and pipe vertices clustering were statistically significant in concurrent locations. The delineated stream desert was then compared to historical maps and documents to confirm the past existence of hydrological connectivity.

Dasymetric mapping techniques were used to identify parts of the city that would benefit from stream daylighting. The analysis implemented population data from 2010 US Census with zoning designations which normalized the spatial data for population; eliminating the perception that people live in Portland's urban forest and open spaces where most of the open stream channels currently exist. With population spatially classified by zoning designations, median household income was overlaid to identify potential for stream daylighting in low to middle class neighborhoods in the study area. 


\subsection{Statistical Analysis}

The mean values of water quality were compared using paired t-tests to detect significant statistical differences in water quality between upstream and downstream locations at a $10 \%$ significance level. The comparison results were used to determine the relationship between land use and stream burial with overall stream health. In order to identify the relationship between impervious area and the percent of piped streams, a Spearman's Rank correlation coefficient was computed across 18 subwatersheds in the lower Willamette Basin. The non-parametric statistic was used as the sample size is relatively small and the data are not necessarily normally distributed.

\section{Results}

\subsection{Portland's Urban Stream Desert}

The early attitude toward urban streams in Portland is well documented in historic articles and ecological literature. An 1895 newspaper article, Rush of the Waters, details an event in which Tanner and Johnson Creeks rush down the west hills of Portland, flooding the main arterials towards downtown and the NW residential area. The article makes mention of the recently built sewers meant to, "swallow up those troublesome creeks (Oregonian; 1895)." Across the country, the filling and draining of surface waters was supported with legislation like the Swamp Land Act of 1850 and the Flood Control Act of 1936. Such legislation incentivized states to not only fill and drain wetlands for agricultural use and urban development, but also to use and alter waterways to maximize beneficial use. These statutes effectively altered 
hydrological connectivity under the premise that waterways are unreliable and flawed in their natural state (Robbins, 1978).

Stream burial has long been the solution to the inconvenient reality of water rushing through prime developable land. Portland's development has resulted in the burial of several streams entirely, and most streams partially. Survey maps of Portland between 1852 and 1860 indicate several lost streams. While newspaper articles recount flood events on the Westside, explorer's journals include descriptions of the eastside terrain of picturesque rolling lands with hydric soils and plants (Douglas, 1914; Fig 5: Survey General's Office, 1852).

Figures $3 \& 4$ below depict downtown Portland in 1860 when Tanner Creek and Jefferson Creek were still open channels.

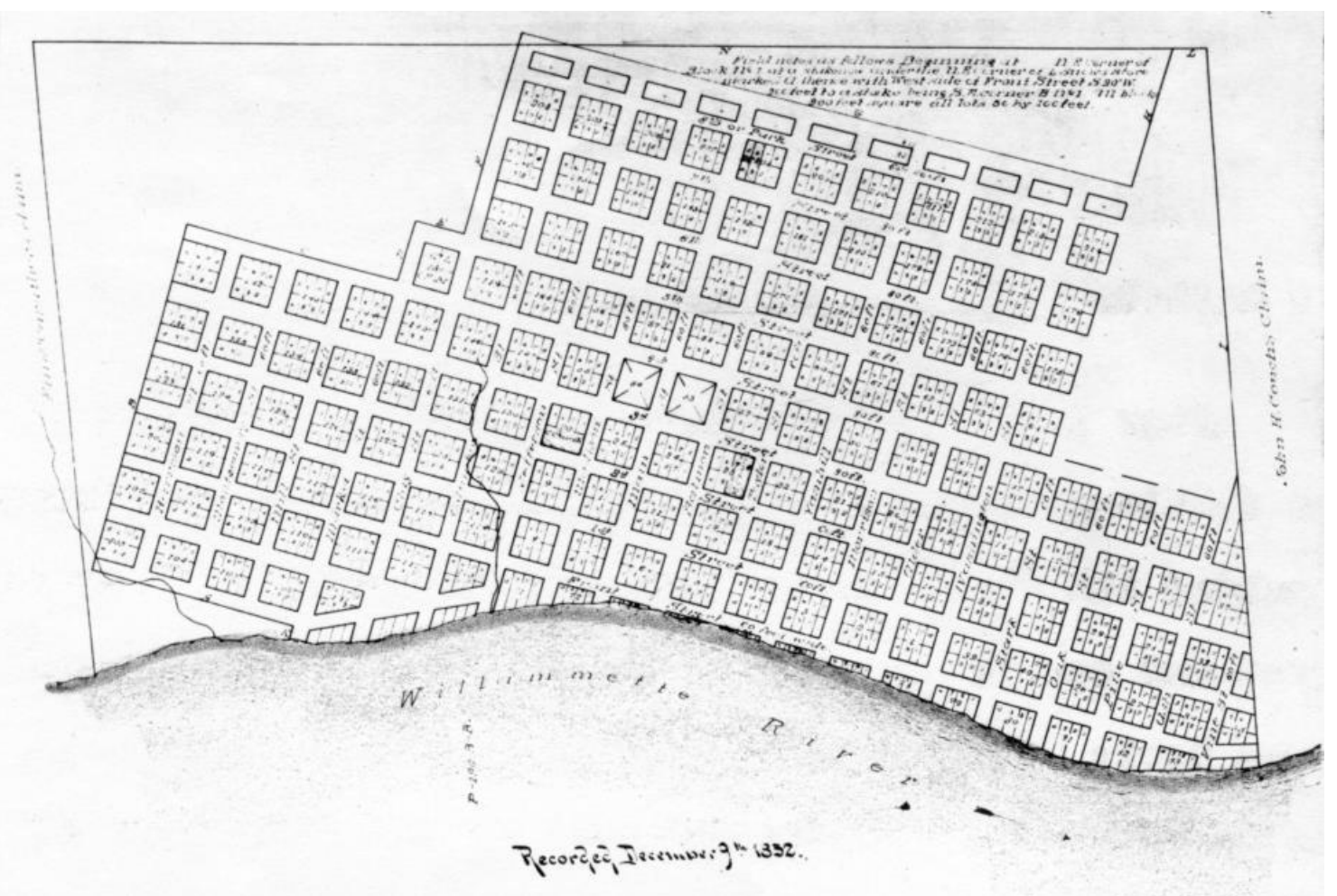

Figure 3: Downtown Portland, 1852. Two streams are visible on the left. Source: City of Portland Archives 


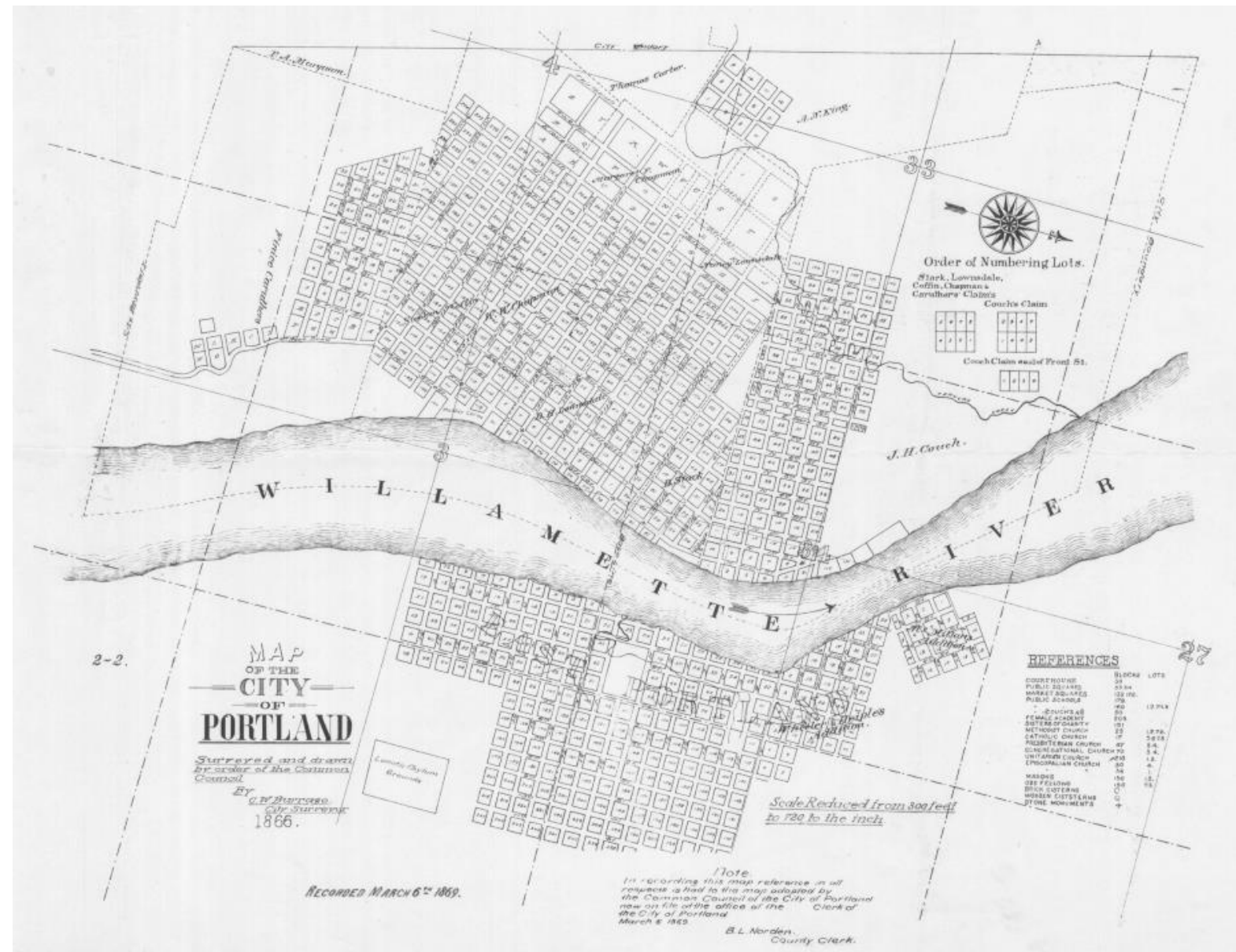

Figure 4: Official Map of the City of Portland 1866. Tanner Creek meanders through the NW corner. Source: City of Portland Archives. 


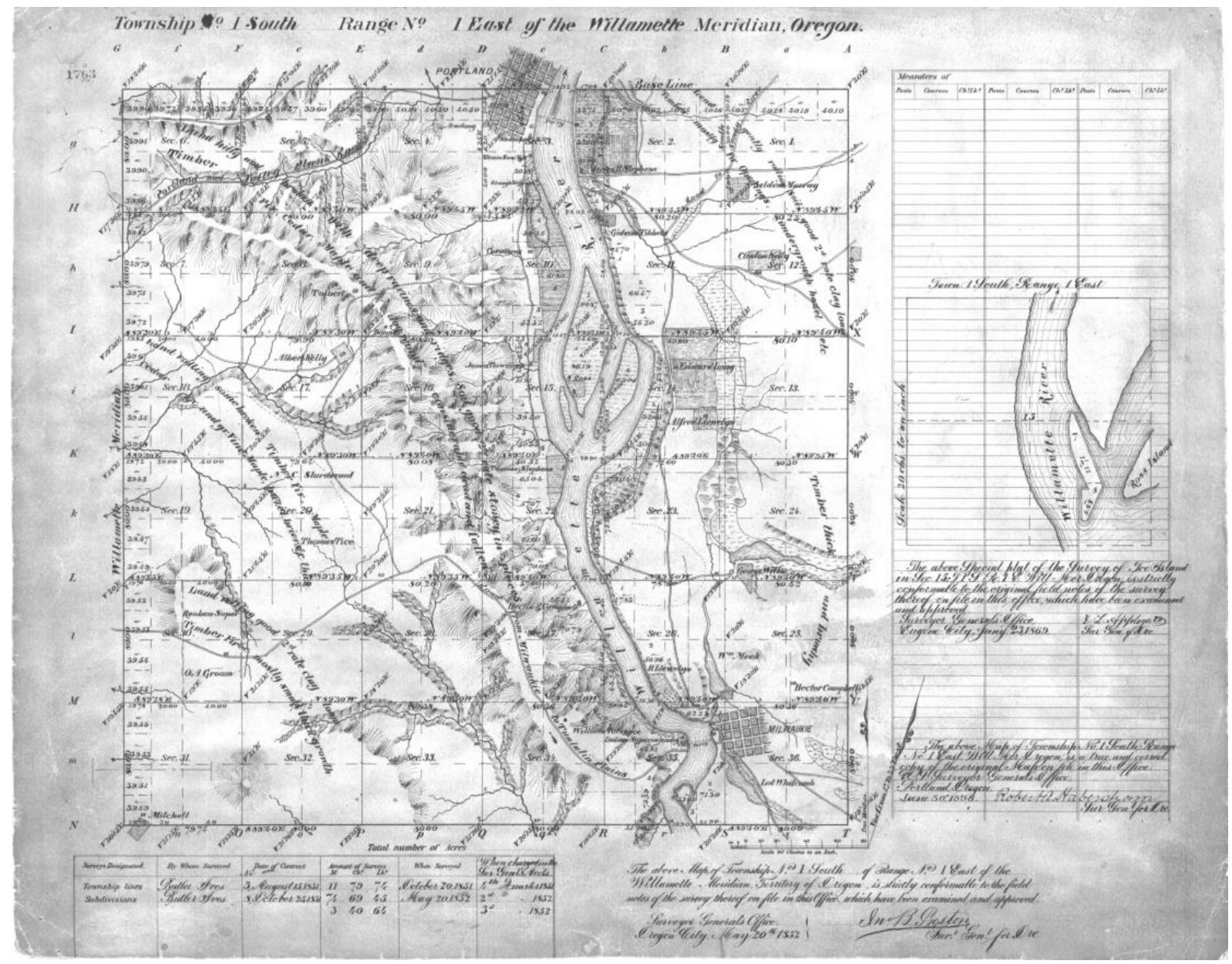

Fig 5: General Land Office Cadastral Survey TS 1S1E, 1852; City of Portland Archives

\subsection{Relation between impervious area and piped streams}

Specific development patterns associated with stream burial include the existence of main arterials and freeway networks, establishment of high density residential neighborhoods, and established sewer and stormwater infrastructure. Given the recent increase in population in the Willamette Basin, 11.3\% from 2000-2010 and a continued projected growth rate of 1.7\% (US Census 2015; 2010), there is a growing demand for high density housing, updated stormwater and sewer systems, and expansion of main arterials. Each of these types of development are synonymous with increased impervious area. 
Impervious area and piped streams are significantly correlated with stream burial. Results of the Spearman's Rank correlation coefficient indicate a strong positive correlation between the two variables $(r=0.938, p<0.01)$. Figure 6 indicates the relationship between buried streams and impervious area for 18 subwatersheds in the lower Willamette Basin; as the percent of impervious area increases, the percent of piped streams also increases. It is interesting to note that the relationship between percent impervious area and percent of stream piped is not straightforward when subwatershed percent impervious area ranges from $30 \%$ to $50 \%$.

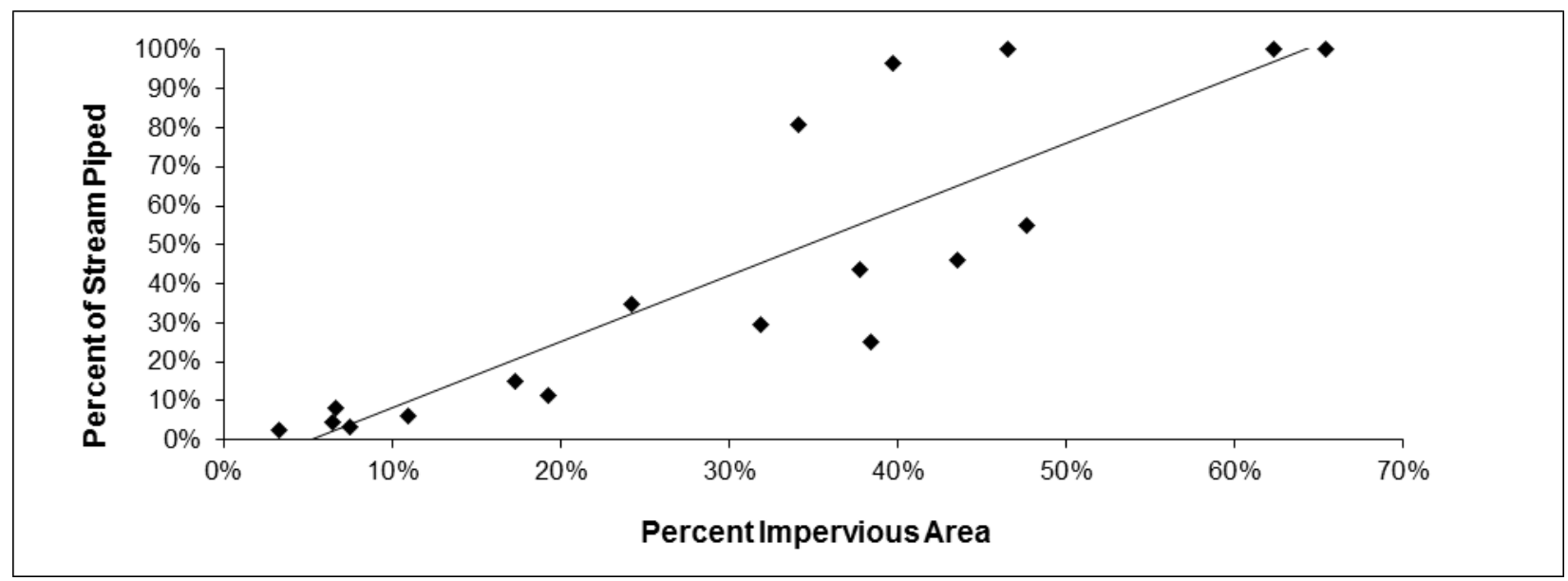

Fig 6: Percent of impervious area to percent of piped stream across 18 subwatersheds in the Willamette Basin

\subsection{Spatial patterns of stream density}

Land use patterns indicate that stream burial is highest in the commercial, industrial, and high density residential areas, and lowest in environmental protection zones and open spaces. While urban stream density analysis reveals that open channels are significantly clustered in Forest Park and along the west side corridor, stormwater pipes and impervious area density are highest in the westside urban core and extend approximately five kilometers east of the Willamette River (Fig 7 and Fig 8). The results indicate an inverse relationship between open channels and stormwater pipe networks. Nearest Neighbor analysis results show significant clustering of all three parameters (Table 3). 


\begin{tabular}{|l|r|r|r|r|r|r|}
\hline & $\begin{array}{l}\text { Observed Mean } \\
\text { Distance (meters) }\end{array}$ & $\begin{array}{l}\text { Expected Mean } \\
\text { Distance (meters) }\end{array}$ & Z-Score & Sig. & CV & Spatial Pattern \\
\hline $\begin{array}{l}\text { Pipe } \\
\text { Vertices (A) }\end{array}$ & 2.6 & 28.6 & -532.7 & 0.00 & -2.58 & Clustered \\
\hline $\begin{array}{l}\text { Impervious } \\
\text { Area (B) }\end{array}$ & 14.9 & 26.3 & -315.8 & 0.00 & -2.58 & Clustered \\
\hline Streams (C) & 74.6 & 145.2 & -40.5 & 0.00 & -2.58 & Clustered \\
\hline
\end{tabular}

Table 3: Nearest Neighbor analysis results; spatial patterns of pipe networks, streams and impervious area.

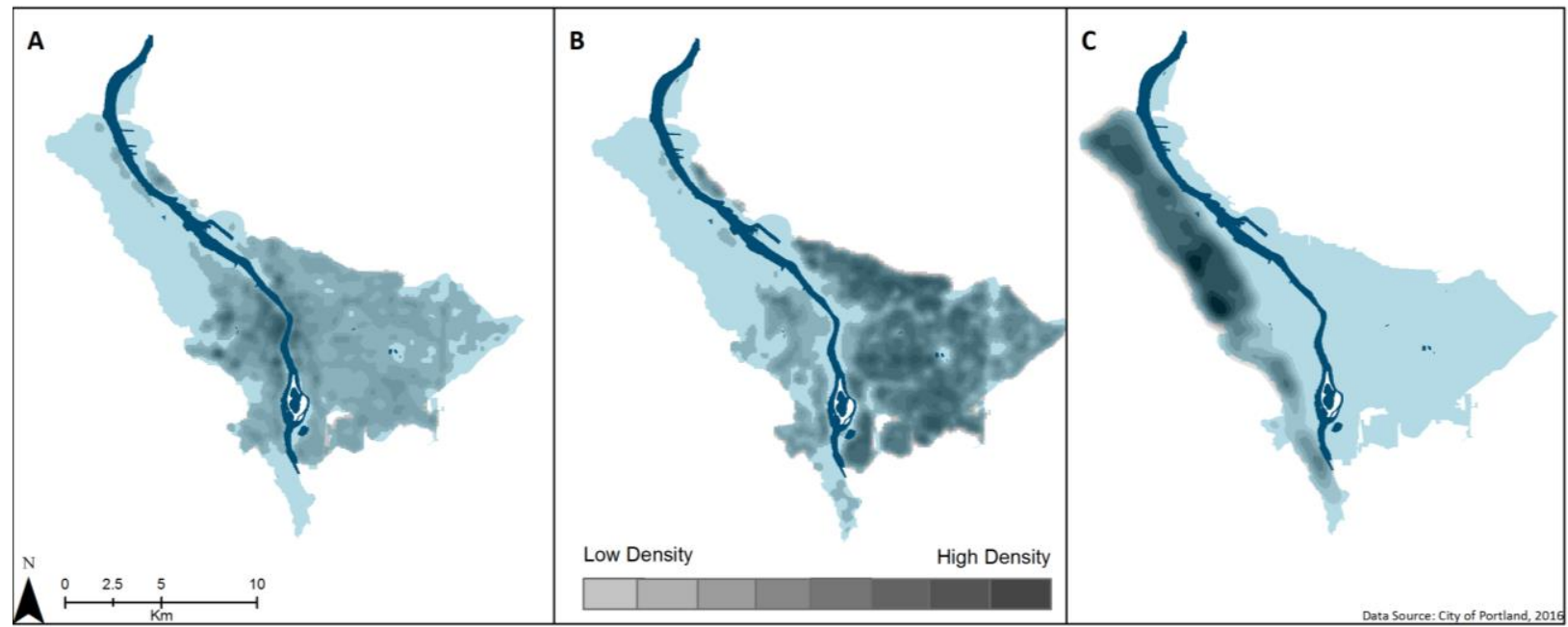

Fig 7: Density overview of (A) pipe vertices, (B) impervious area and (C) open streams in the Willamette Basin.

The delineated urban stream desert is derived by detecting significant clustering of stormwater pipes and impervious area on the East side of the Willamette River and in downtown Portland. When the significant clustering of each parameter was combined, the delineation indicates a vast urban stream desert on the East side of Portland, extending nearly to the eastern boundary of the lower Willamette drainage basin. Figures 8 (a) and (b) depict the significant clustering of stormwater pipes and impervious area. Figure 8 (c) is a representation of the two combined. 


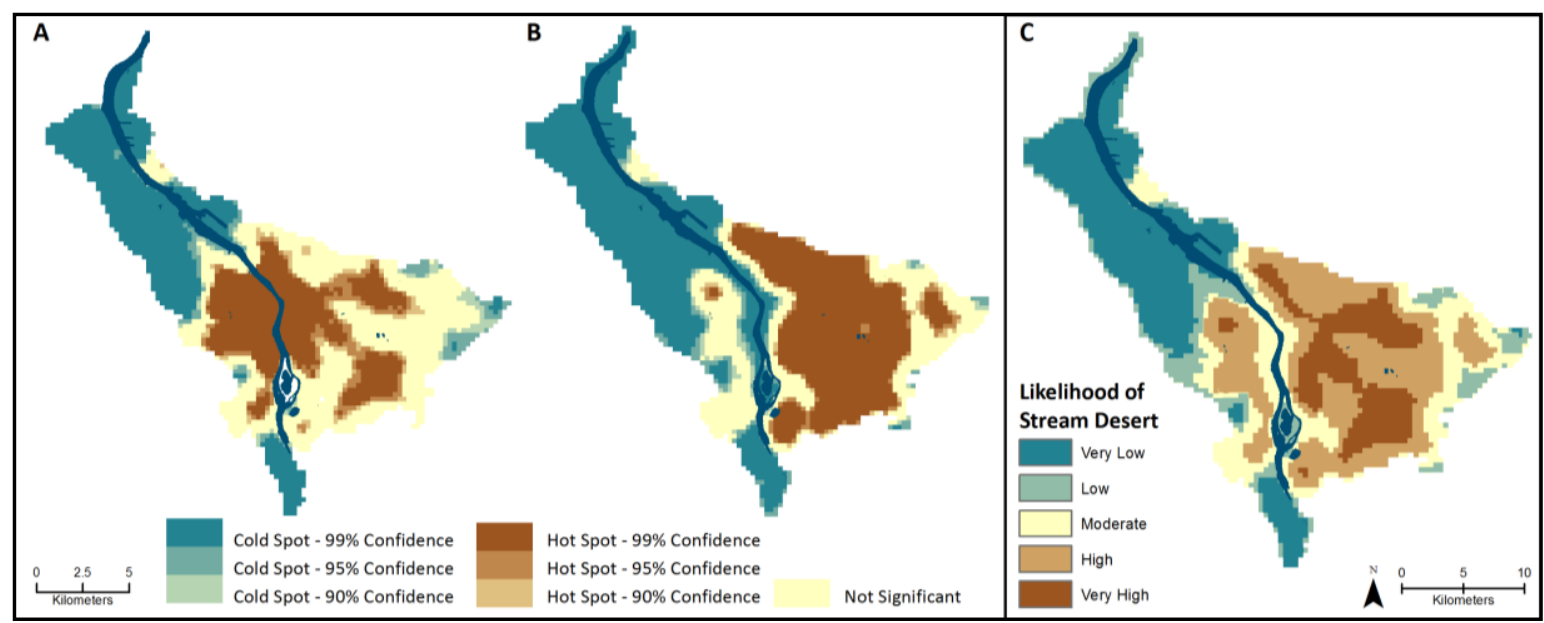

Fig 8: Portland's delineated stream desert.

\subsection{Impacts of burial on water quality}

Table 4 details the p-values of the paired t-tests for each stream and water quality parameter. Tanner (55\% piped) and Saltzman (3.27\% piped) show significant differences in four out of the five water quality parameters between the upstream and downstream sites. Land use patterns in each of these subwatersheds are the most varied, ranging from conservation zones to commercial and industrial areas (Figure 2). Miller Creek (2.71\% piped) had three out of five parameters with significant differences between sites. Stephens Creek (29.6\% piped) is perhaps the most degraded of the streams in the study and showed very little difference between upstream and downstream sites. Doane Creek, with the least varied land use of the study area, exhibited only one parameter (temperature) with a significant difference.

\begin{tabular}{|c|c|c|c|c|c|c|c|}
\hline Stream & DO & Conductivity & TSS & pH & Temp & $\begin{array}{l}\text { \% } \\
\text { Impervious }\end{array}$ & \% Piped \\
\hline Tanner & $0.0863^{*}$ & $0.0385^{* *}$ & n.s. & $0.0697^{*}$ & $0.0001^{*}$ & $47.65 \%$ & $55.03 \%$ \\
\hline Stephens & n.s. & n.s. & n.s. & $0.0487^{*}$ & n.s & $31.88 \%$ & $29.63 \%$ \\
\hline Saltzman & $0.0639 *$ & $0.0548 *$ & $0.0898^{*}$ & n.s. & $0.0138^{*}$ & $7.54 \%$ & $3.27 \%$ \\
\hline Doane & n.s. & n.s. & n.s. & n.s. & $0.0653^{*}$ & $6.69 \%$ & $4.69 \%$ \\
\hline Miller & n.s. & $0.0001 * * *$ & $0.0894 *$ & $0.0426^{*}$ & n.s. & $3.32 \%$ & $2.71 \%$ \\
\hline
\end{tabular}

Table 4: P-value results for paired T-Tests comparing upstream and downstream sites.

$*$ = Statistically significant at the 0.1 level, $* *=$ statistically significant at the 0.05 level; $* * *=$ statistically significant at the 0.01 level, n.s $=$ not significant 


\subsection{Stream daylighting potential}

Figure 9 combines median household income (9a) and population (9b) to determine areas of Portland with a combination of high population density and low to medium income levels. The darker shaded areas in figure 8c indicate parcels with a median household income of $\$ 6,885$ $-\$ 35,546$ and a population density of $240-1,900$ people per $5 \mathrm{~km}^{2}$. Figure $9(\mathrm{c})$ exhibits a random distribution of parcels meeting the criteria on the east side in the urban stream desert, and a clustered distribution in the densely populated downtown area.

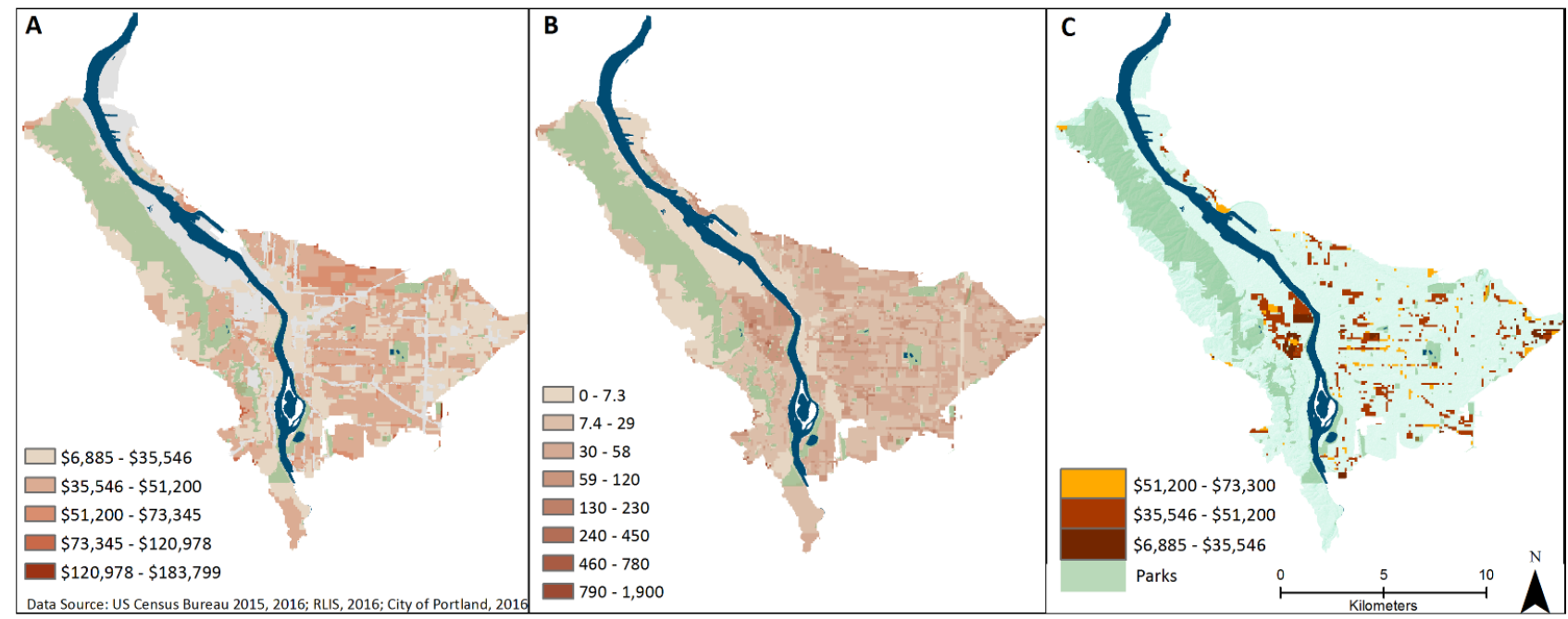

Fig 9: Population and Median Household income as social criterial for identifying locations for stream daylighting; (A) Median Household Income, (B) Population density per $5 \mathrm{~km}^{2}$, (C) Combination of overlapping areas with population density of $240-1,900 \mathrm{~km}^{2}$ and median household income between $\$ 6,885-\$ 73,300$.

Of the five subwatersheds in the study area, three reveal locations that fit the base social criteria for project locations: (A) Miller Creek, (B) Tanner Creek, and (C) Stephens Creek (Figure 10). 


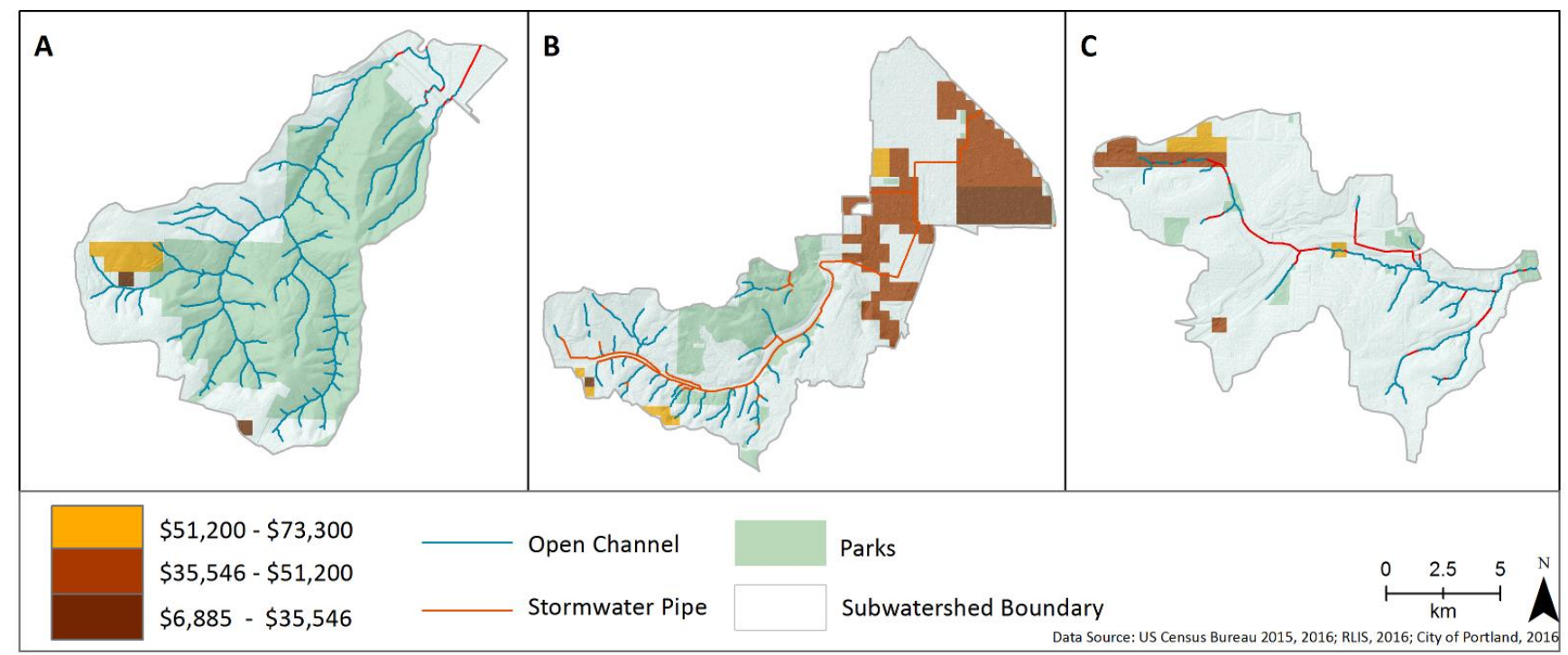

Figure 10: Subwatershed comparison of Population and Median Household income as social criterial for identifying locations for stream daylighting.

\begin{tabular}{|c|c|c|c|}
\hline Subwatershed & $\begin{array}{l}\text { Meets Social Criteria } \\
\text { (hectares) }\end{array}$ & $\begin{array}{l}\text { Length of Pipe } \\
\text { (m) }\end{array}$ & $\begin{array}{l}\text { Length of Pipe Running through } \\
\text { Criteria Area (m) }\end{array}$ \\
\hline Miller Creek & 11 & 589 & 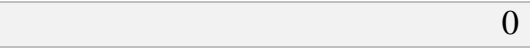 \\
\hline Tanner Creek & 192 & 10,706 & 2,813 \\
\hline Stephens Creek & 17 & 2,313 & 66 \\
\hline
\end{tabular}

Table 5: Comparison of Potential Daylighting Locations based on Social Criteria

In comparing the three subwatershed areas, the analysis indicates that the lower reach of Tanner Creek stands out as a potential candidate due to the combination of dense population and low to middle range median household income. Tanner Creek runs through 10,706 meters of pipe of which 2,813 meters is routed through parcels that meet the social criteria. Comparatively, there are no pipes in Miller Creek that run through parcels meeting the social criteria. Stephens Creek has 66 meters of pipe running through parcels that meet the social criteria, however, they are culverts that run under major arterials and would not be suitable for daylighting. 


\section{Discussion:}

\subsection{Spatial patterns of stream desert and its relation to history of development}

Spatial patterns indicate that urban development is the major underlying cause of stream burial. It was (and often still is) common practice in urban development to pipe streams wherever possible rather than face the inconvenience of building around them. Historic records have shown that the Eastside of Portland was the first to be subject to urban sprawl given its flat topography; highly accessible for residential and industrial development. Conversely, Portland's Westside is characterized by steep hills and unstable soils making it much less conducive to development. Portland's early Westside development was mainly limited to the flat lowlands near the Willamette River. In many ways, Portland's varied topography defined which streams have been buried and which have remained open channels.

While stream burial is directly related to urban development, there may not be a linear relationship between stream burial and percent of impervious area. Figure 6 indicates that for subwatersheds with between 30\% - 50\% impervious area, the percent of piped stream varies by as much as $70 \%$. Subwatersheds in the non-linear category should be examined more closely for restoration potential. For example, a subwatershed that has lower percent of impervious area than the percent of piped stream, may have more potential sites for daylighting. Streams on the westside fit such criteria due to the large open spaces that are not available for development. Subwatersheds with $80 \%-100 \%$ of the stream piped, regardless of impervious area, appear to have very little potential for restoration due the severe lack of connectivity and surrounding built environment. 


\subsection{Impacts of development on stream degradation}

Stream function and health are heavily impacted by the change in drainage patterns in urban catchments (Julian et al, 2015; Wietzel et al, 2016). While natural streams retain water and function in a way that allows the absorption and filtration of nutrients, urban drainage networks convey water and pollutants directly into receiving streams (Walsh et al, 2016). The upstream and downstream comparison results support the argument that piping streams, confounded by urban development, diminishes stream health and functionality.

The stream degradation associated with urbanization includes increased flashiness, reduced biodiversity, altered geomorphology, and increased nutrient loading (Julian et al, 2015; Walsh et al., 2016; Wietzel et al, 2016). With the increase of impervious area, stormwater moves more quickly into both open channels and stormwater drains. Not only does this contribute to a flashy hydrograph, but it also provides a conduit for pollutants to go directly into the streams and rivers without the opportunity to filter through vegetation and soil (Hatt et al, 2004; Walsh et al, 2005; Jacobson, 2011). Additionally, the increase of impervious area and loss of permeable soils and wetlands reduces groundwater recharge, negatively impacting base flow (Chang 2007, Hale et al., 2015; Walsh et al. 2012). Habitat loss associated with altered stream channels have contributed to increase of invasive species and limited fish passage (Cooper et al, 2013).

While stream degradation is widely known to be associated with urbanization, measuring the impact of urbanization has proven to be challenging due to the variation across urban areas and the difficulty in referencing a target condition. For instance, there are several streams just outside the Portland area that are not impacted by urbanization, however they are experiencing degradation associated with rural agricultural runoff (Pratt and Chang 2012). By analyzing water 
quality parameters between upstream and downstream sample points of several urban streams, impacts of urban development can be compared across a variety of land uses.

Limitations to these results include the difference in data points and number of observations. With the exception of Doane Creek, there were many more observations for the downstream points than the upstream points. Given the nature of observational data and the confounding factors of urban development and stream health, it is difficult to determine whether increased stream burial is a direct cause of degraded water quality, or whether it works in tandem with other factors that contribute to degraded water quality (such as land use patterns and existence of major roads). Patterns in urban development and variation of land use are often synonymous with both stream burial and degradation, indicating that a more controlled data collection design would be necessary to further assess the impacts of stream burial on water quality.

\subsection{Impacts of stream burial on water quality in relation to regulatory standard}

The Oregon Administrative Rules (OAR 340-041-0016(3)) mandates that Dissolved Oxygen in waters supporting cold water aquatic life may not fall below $8.0 \mathrm{mg} / \mathrm{L}$ as a 30 -day mean minimum, $6.5 \mathrm{mg} / \mathrm{L}$ as a seven-day minimum mean, and may not fall below 6.0 as an absolute minimum (DEQ, 2004). While each of the streams are within the acceptable range, every stream in the study has a decrease in DO between the upstream and downstream reaches with an average decrease of $.5 \mathrm{mg} / \mathrm{L}$ among all the streams. In urban streams, decreased dissolved oxygen is caused by reduction in stream riffle and stream bank complexity; a possible consequence of piping. 
The Oregon Department of Environmental Quality provides guidelines for stream temperatures with seven day average maximums between $13^{\circ} \mathrm{C}$ and $18^{\circ} \mathrm{C}$ depending on the cold water aquatic life supported in streams (OAR 340-041-0028) (DEQ,2004). While none of the streams in the study reached the maximum allowable temperature, a general trend of temperature increase can be noted between upstream and downstream locations. Tanner Creek had the largest average temperature increase from the headwaters to the outfall with difference of $5.6^{\circ} \mathrm{C}$. Stephens Creek had the smallest change in temperature which could be explained by the homogeneity of land use (70\% residential development) throughout the subwatershed. Additional analysis of the downstream temperature data revealed that while Tanner Creek was an average of $6^{\circ} \mathrm{C}$ lower than the main stem Willamette River in the hottest months, it was still an average of $4^{\circ} \mathrm{C}$ warmer than comparable neighboring streams. Changes in temperature not only impact the geographic distribution of cold water species, but also have cumulative watershed impacts which include the determination of chemical and biological processes (Mayer, 2012; McCullough et al., 2009). Further research is necessary to determine whether daylighting Tanner Creek in strategic areas would reduce the temperature on the hottest days and provide a refuge for cold water habitat.

While water quality criteria have not been established for TSS, its positive correlation with other stormwater pollutants is widely known (Maybeck et al, 2002; Gray et al, 2000). The Portland Stormwater Management manual acknowledges the that increases TSS levels are related to urban development and requires a $70 \%$ removal of TSS from $90 \%$ of the average annual runoff from new development. While the USEPA has yet to set guidelines on TSS levels, The Ministry of Environments Land and Park, British Columbia has set a measurement guideline of $25 \mathrm{mg} / \mathrm{L}$ for aquatic life (Singleton, 2001). Tanner, Saltzman and Miller Creeks each show 
very large increases in TSS with differences between upstream and downstream sites, ranging from 26-37 mg/L. Doane and Stephens Creeks show a reduction in TSS between the upstream and downstream sample sites. While further research is required to understand the relationship between land use and TSS, the parameter is still a viable indicator of subwatershed health and can be considered in watershed management decision making.

Similarly, while there are no regulatory levels of conductivity, it can be a good indicator of pollutants that may exists in the water including salinity and dissolved solids. Abrupt changes in conductivity can affect aquatic life that have adapted to certain ranges of specific conductivity in their habitat. Tanner and Miller Creeks had the largest mean difference in conductivity levels between upstream and downstream sites, indicating that cold water migratory habitat would potentially be confined to specific areas in the streams given that pipes and culverts were passable.

The Oregon Administrative Rules (OAR 340-041-0345(b)) states that $\mathrm{pH}$ values may not fall outside the range of 6.5 to 8.5 for all waters in the Willamette Basin. No Creeks in the study exceed the maximum or fall below the minimum; Tanner Creek was the only stream to show an increase in value.

\subsection{Stream daylighting potential}

Stream daylighting efforts in Portland have focused both on social and ecological benefits. The Spring Garden Park daylighting project daylighted 300 feet of open channel and included the implementation of native plants attractive to pollinator species (BES, 2016). This project features interpretive educational signage in a public park near a children's playground, supporting an educational opportunity for the surrounding community to participate in stream 
restoration in the headwaters of Tryon Creek. Just downstream from Spring Garden Park, another segment of the headwaters stream was daylighted as part of the design for an affordable housing project built in 2006. This project confirms that new urban development can implement open stream channels in landscaping rather than diverting to pipes or culverts. Another notable project in Portland is Tanner Springs Park, located downtown. While this project did not technically daylight Tanner Creek, it serves as a constructed urban wetland, nesting site for birds, fish habitat, stormwater detention pond and a memorial of the historic route of Tanner Creek which runs in a pipe directly under the park.

It must be acknowledged that there are many complex factors when determining the feasibility of stream daylighting; i.e. rate-payer agreement, private property owner compliance, combined sewer system separation, and maintenance obligations. These factors cannot always be accurately modelled or quantified and require consideration on a case by case basis. Indeed, further multi-criteria analysis of the east side urban stream desert would be necessary given the severely altered stream routes; in many cases historic streams have been routed through the sewers and combined on the way to the waste water treatment plant. While a multi-criteria model for identifying potential sites for daylighting is beyond the scope of this study, this analysis offers a start at identifying potential sites with a spatial equity lens. Median household income and population density can be used as parameters for finding areas where the most people will benefit from a daylighting project. As such, this comparison method used in our current study can be used as a starting point for identifying project locations that would meet the needs of the community. 


\section{Conclusion:}

This study was initiated by four key goals related to stream burial in Portland, Oregon:

(1) To examine the history of urban stream burial, (2) to determine the patterns of stream burial and its relationship with impervious area, (3) to identify impacts of stream burial on water quality, and (4) to identify the social and ecological benefits of stream daylighting.

Archival analysis was performed to confirm the past existence of hydrological connectivity in the city, and to provide a historic lens to the reason behind aggressive stream burial. It can be concluded that early urbanization, the implementation of the Portland's sewer and road infrastructure, and the attitude that urban streams impede development, have each contributed heavily to stream burial in Portland. It has been determined that topographical characteristics have largely defined which streams get piped and which do not. Flat topography on the east side has resulted in easier development and subsequently the existence of a vast urban stream desert. Portland's urban stream desert was delineated through spatial analysis and determined to cover $85 \%$ of the east side of the lower Willamette basin.

This study has identified a strong correlation between urban development and urban stream loss. Water quality analysis reveals that greater changes in water quality occurred in the streams with greater variation of land use. While the percent of pipe present in a stream was not a consistent indicator of all water quality parameters, given the association with urban development it can be argued that stream burial is associated with reduced water quality. This is particularly true for parameters such as DO and TSS which are heavily impacted by changes in channel complexity. This study is consistent with other research asserting that there are several confounding factors associated with land use, stream burial and stream degradation. 
Robust research has revealed the positive implications of implementing natural landscapes, however small, into urban environments. Recent efforts to design around existing nature and daylight streams in urban areas have contributed to improved water quality, increased biodiversity, increased community engagement, and reduced strain on aging sewer infrastructure. By modeling a citywide daylighting policy such as that used in Zurich, Portland could see a substantial reduction in combined sewer overflows, and provide habitat and hydrological connectivity for biological communities. This study has shown that stream daylighting not only provides ecosystem services, but also demonstrates the important intersection between urbanization and conservation.

\section{References}

Broadhead AT, Horn R, Lerner D (2015) Finding lost streams and springs captured in combined sewers: A multiple lines of evidence approach. Water and Environmental Journal 29: 288-297

Bureau of Environmental Services (2011) Tanner Creek Water Quality Characterization Report. City of Portland.

Chang H (2007) Streamflow characteristics in urbanizing basins in the Portland Metropolitan Area, Oregon, USA, Hydrological Processes 21(2): 211-222

Chen H, Chang H (2014) Response of Discharge, TSS, and E.coli to Rainfall Events in Urban, Suburban, and Rural Watersheds. Environmental Science: Processes and Impacts 16 (10): 2313 - 2324

Clayton S, Myers G (2009) Conservation psychology: understanding and promoting human care for nature. Chichester: Wiley-Blackwell

Conradin F, Buchli R (2004) The Zurich Stream-Daylighting Program. Enhancing Urban Environment by Environmental Upgrading and Restoration. Kluwer Academic Publishers; Netherlands. 277-288

Douglas D (1914) Journal kept by David Douglas during his travels in North America, 1823-1827. William Wesley \& Son London. https://archive.org/details/journalkeptbydav00dougiala

General Land Office Cadastral Survey TS 1S1E (1852) City of Portland Archives. https://www.portlandoregon.gov/bps/article/146727 Accessed 11 April 2017

Gray J, Glysson DG, Turcios LM, Schwarz, GE (2000) Comparability of suspended sediment concentration and total suspended solids data. USGS Water Resources Investigation Report 00-4191. https://water.usgs.gov/osw/pubs/WRIR00-4191.pdf Accessed 26 January 2017 
Elmore AJ, Kaushal SS (2008) Disappearing streams: patterns of stream burial due to urbanization. Frontiers in Ecology and the Environment 6,6:308-312.

Jacobson C (2011) Identification and quantification of hydrological impacts of imperviousness in urban catchments: A review. Journal of Environmental Management 92: 1438-1448.

Julian JP, Wilgruber NA, de Beurs KM, Mayer PM, Jawarneh (2015) Long-term impacts of land cover changes on stream channel loss. Science of the Total Environment 537:399-410

Maybeck M, Laroche L, Durr HH, Syvitski JPM (2003) Global variability of daily total suspended solids and their fluxes in rivers. Global and Planetary Change 39: 65-93.

Mayer TD (2012) Controls of summer stream temperature in the Pacific Northwest. Journal of Hydrology. 457: 323-335.

McCullough DA, Bartholow JM, Jager HI, Beschta RL, Chelsek EF, Deas ML, Ebersole JL, Foott JS, Johnson SL, Marine KR, Mesa MG, Petersen JH, Souchon Y, Tiffan KF, Wurtsbaugh WA (2009) Research in thermal biology: burning questions for coldwater stream fishes. Reviews in Fishery Science. 17(1):90-115.

Miller JR, Hobbs RJ (2002) Conservation where people live and work. Conserv Biol 16:330-337

Miller JR (2006) Restoration, reconciliation, and reconnecting with nature nearby. Biol Conserv 127:356361

Miller JR, Snyder SA, Skibbe AM, Haight RG (2009) Prioritizing conservation targets in a rapidly urbanizing landscape. Landscape and Urban Planning, 93:123-131.

Napieralski JA, Carvalhaes (2016) Urban stream deserts: Mapping a legacy of Urbanization in the United States. Applied Geography 67: 128-129.

Neale M, Moffett E (2016) Re-engineering buried urban streams: Daylighting results in rapid changes in stream invertebrate communities. Ecological Engineering 87:175-184

Official Map of the City of Portland (1866). City of Portland Archives. https://www.portlandoregon.gov/bps/article/146718 Accessed 11 April 2017

Ord JK, Getis A (1995) Local spatial autocorrelation statistics: distributional issues and an application. Geogr. Analy. 27:286-306

Pratt B, Chang H (2012) Effects of Land Cover, Topography, and Built Structure on Seasonal Water Quality at Multiple Spatial Scales, Journal of Hazardous Materials 209/210: 48-58.

Pinkham R (2000) Daylighting; New life for buried streams. Rocky Mountain Institute, Colorado. Print.

Robbins WG (1978) The Willamette Valley Project of Oregon: A Study in the Political Economy of Water Resource Development. Pacific Historical Review. 47(4):585-605

Singleton H (2001) Summary of Water Quality Guidelines For Turbidity, Suspended and Benthis Sediments. Ministry of Environment, Lands and Parks; British Columbia, Canada. http://www2.gov.bc.ca/assets/gov/environment/air-land-water/water/waterquality/wqgswqos/approved-wqgs/turbitity-or.pdf Accessed 17 April 2017 
Smith, BR (2007) Assessing the Feasibility of Creek Daylighting in San Francisco, Part I: A Synthesis of Lessons Learned from Existing Urban Daylighting Projects. Water Resources Center Archives. UC Berkeley: Water Resources Collections and Archives. http://escholarship.org/uc/item/4m48c7x7 Accessed 18 January 2017

Standish R, Hobbes RJ, Miller JR (2016) Improving City Life: options for ecological restoration in urban landscapes and how these might influence interactions between people and nature. Landscape Ecology, 28:1213-1221

State of Oregon, Dept of Environmental Quality (2004) Water Quality Standards: Beneficial uses, policies and criteria for Oregon. OAR, Chapter 340, Division 041. http://www.nwd-

wc.usace.army.mil/tmt/wqnew/state standards/or/2004 Chapter 340 Div 041.pdf accessed 20 March 2017

Survey of Portland (1852) City of Portland Archives. https://www.portlandoregon.gov/bps/article/146700 Accessed 11 April 2017

Tong S, Chen W (2002) Modeling the relationship between land use and surface water quality. Journal of Environmental Management 66: 377-393

United States Census Bureau (2010) U.S. Decennial Census and American Community Survey results: 2000-2010 State of Oregon Population by county.

http://www.oregon.gov/das/OEA/Pages/surveyresults.aspx

Walsh CJ, Roy AH, Feminella JW, et al. (2005) The urban stream syndrome: current knowledge and the search for a cure. Journal of the North American Benthological Society 24(3):706-723

Walsh CJ, Fletcher TD, Vietz GJ (2016) Variability in stream ecosystem response to urbanization: Unraveling the influences of physiography and urban land and water management. Progress in Physical Geography Vol 40(5):714-731

Weitzell RE, Kaushal SS, Lynch LM, Guinn SM, Elmore AJ (2016) Extend of Stream Burial and Relationships to Watershed Area, Topography and Impervious Surface Area. Water 8:538; doi:10.3390/w8110538

Wilbur DH, Clarke DG (2001) Biological Effects of Suspended Sediments: A review of Suspended Sediment Impacts on Fish and Shellfish with Relation to Dredging Activities in Estuaries. North American Journal of Fisheries Management Vol 41(4):855-875 doi:10.1577/1548-8675(2001)021

Wild TC, Bernet JF, Westling EL, Lerner DN (2011) Deculverting: reviewing the evidence on the 'daylighting' and restoration of culverted rivers. Water and Environment Journal, 25: 412-421. doi:10.1111/j.1747-6593.2010.00236.x 